\title{
Local Media Going Global: Assessing Online Media Efficiency By Nigerian Audience Abroad
}

\author{
Adelakun, Lateef Adekunle \\ National Open University of Nigeria, Nigeria \\ ladelakun@noun.edu.ng
}

\begin{abstract}
The internet connectivity is projecting the opportunities upon which local mainstream news media (newspaper, radio and television) are reached globally. Even outside the comfort zones of the newspaper circulation as well as radio and Television spectrums, the internet makes a point of contact between the media and the audiences across borders. Assessing the purpose for media going global, which transcends reaching the audience outside the border-bound but accommodates the effort to meet up with the information needs of the international audience, constitutes the major objective of this study. A survey of the diaspora audience of Nigerian online media in Malaysia, UK, South Africa, and the US was conducted through online questionnaire. Sampling the opinions of the media audiences across frontier on whether the media globalisation enhances the quality and structure of media output, this study found out that despite the fact that the general audience assessment of the media was lamentable, the audience appraised newspapers for moving closer to the global prospect ahead TV and Radio. The audience rating of the online media efficiency was discussed on the tenet of media usage based on the information needs that compel gratification. The online access to mainstream media according to the audience remains a laudable innovation that upturns the media questionable outputs and narrows the wide gaps between the media and the audience as well as among the audiences.
\end{abstract}

Keywords: Media efficiency, Media globalisation, Digital Natives, Digital immigrants, Communicating-development.

\section{INTRODUCTION}

Facing the challenge of audience migration to the new media owing to information globalization and instantaneous access to online news through internet connectivity and World Wide Web networks, mainstream media (radio television and newspaper) fret over going to extinction. As the viewership of television and listenership of radio dropped, so also the hours spent viewing or listening by the loyal audience of the broadcast media shrinks (Bucy, 2003). A significant part of prime times in the broadcast media (usually the evening period,) during which radio and television make family prestigious moments, is lost to online 
news search and information sharing benefit. A more tensed scenario also blurred offline newspaper chance of survival in the media market. The information delayed in the offline newspaper modality of news reports mounted more pressure on its presence and ability to compete for a sizable segment of the audience to make an impact in the media market. As the rate of internet literacy increases particularly among the youth age and the access to internet grows (Mitchelstein \& Boczkowski, 2009) at the time data charges become reasonably affordable to the middle class and the internet needy among the lower class, mainstream media needed to align with online news mode. The alignment led to the introduction of online editions of newspapers and broadcast streaming in the case of radio and television with the aim to reach their elusive internet audience, who keenly search for quick accessed summary news (Chan \& Leung, 2005).

Also, the online alignment is not a peculiarity of mainstream media in Nigeria but a global information trend toward instantaneous news across borders and beyond the reaches of the mainstream news media. The belief that online news and social media networks have exacerbated what Messing and Westwood (2014, p. 1042) describe as "fragmentation of the media and the citizenry" to achieve media polarization and selective exposure from crowded information relay industry, confirms the keen competition for audience attention. In a bid to establish the rate of audience satisfaction from the online innovation version of the mainstream media, this study surveys the opinions of the actual use of the media. The audience opinions are discussed from the three parameters that the study picked to analyze the media efficiency: how credible the media based on the credibility of the news it reports; how accessible the media to meet the quick and instantaneous information need of the audience; and how interactive the media in term of feedback advantage to ensure active audience rather than the passive characteristic of the mainstream media audience.

As a prelude to the discussion on the audience reactions to the innovation of online news media, the influence of online literacy rate on media preferences among the audience forms part of the discussion. Also, on the premises of uses and gratification theoretical approach, it discusses the audience interests in and evaluation of the media contents, which satisfy their needs and upon which the audience decisions on media consumption are based. The theoretical perspective grounds the explanations on media selectivity among the audience as well as the innovations in media contents and structure to meet the taste of the target audience. It also serves as the bases for the explanation of fragmentation of the media market in the face of audience demographic and psychographic variances which dictates individual uniqueness in their expectations from the media or variation in their need to be gratified upon which they consume media contents.

\section{Online News Innovation and Effect of Internet Literacy Rate}

The argument on whether online media were supplementing or displacing mainstream media has attracted empirical studies (Graham and Greenhill (2013); Kim (2006); Mitchelstein and Boczkowski (2009); Nguyen and Western (2006)) in a bid to explain audience behaviours both in media selection as well as in the variance of their information needs. The digital native nature of every successive generation of media audience compared to digital migrant nature of previous generations of audience constantly and continuously increases the audience information needs beyond the provisions of the mainstream media thereby making the quests for supplementing media outlet irresistible. The quest to satisfy information needs also boost 
the interests in online literacy rate, an important condition that enhance the information utility in new media.

The era of pure news-driven journalism characterised by the passive and informationfed audience is fading away as more and more audience embrace and adapt to innovations that enhance information sharing and distribution (Adelakun, 2018). Information is no more unidirectionally transmitted but rather a participatory and collaborative activity as the online audience could share information freely and instantaneously through interactive platforms (Kim, 2006). The idea that information is now at fingertips through internet-provision and online sources is plausible as the audience are growing in the basic knowledge of online information search and sharing tools. The domination of the digital native audience of the internet platform does not alone diffuse the media message to the negligence of the digital immigrant audience but also encourages many of the digital immigrants to keep abreast of new knowledge to access online information in order to fulfil their information demands.

\section{Mainstream Media in a Quest to Survive Audience Drought}

Increase in affordability and accessibility of internet according to Benson et al.(2012) enhances advertising and information provision in some region while in some other, it yields more opinions and deliberation. In both regions, media audience is at a beneficial end as their voices in what the media reports grow louder to make them active. As the online rebranding of mainstream media creates many opportunities for the audience to access, explore and censor the media messages, the audience are reverting to the restructured mainstream media to add to their online information access and information gain. The reversion comes with a reformed mainstream media as well as the reformed audience, who play active roles in what constitute the media contents. The belief that internet caters for different sources of information and as a result unites people of similar interests, who eventually form internet communities (Wojcieszak, 2009), has given rise to the ratio of the informed audience of the rebrand mainstream media.

Some factors such as media trust based on the credibility that the media earned from the audience; the audience involvement in issues reported about them; and the unrestricted access to the media and its messages are among the key consideration for media selection or selective exposure to media messages. It is logical that media audiences are attracted and get exposed to the media they trust (Tsfati, 2010); which satisfy their information and communication demands. As soon as the mainstream media realised that the routine journalistic style does not fit-in to the online platform as it is considered "inaccurate, sensational and self-motivated" (p. 24) and thereby repels the audience, the online version is embedded with audienceinvolved information sharing and audience-trust information sources for authentication. There was also a need for the mainstream media to abide by the boundlessness nature of online information structure; constantly keeping and disseminating up-to-date information that updates the audience on a round-the-clock basis.

\section{Uses and Gratification Theoretical Approach to Online Media}

The audience sociological or psychological information needs, upon which media selections are made for utility purposes (Leung \& Wei, 2000) has ignited various studies in communications in general and online media in particular. Looking at the individual usage of the media rather than media influence on the audience, the tenet upon which Uses and 
Gratification theory reclined, berates both powerful media effect as well as passive audience concepts (Urista, Dong, \& Day, 2009). Uses and Gratification theory defines the audience information as the core for media selectivity, preference and consumption. Exposure to media information is now induced by the needs that the audience wants to satisfy as the increase in the information outlets compels competition for audience attention among various media. The emergence of online media further brakes information monopoly and thereby allows more information suppliers in the media industry.

The amount of information available online as well as the interactive communication opportunity significantly raise not only the usage of online media but also enhances gratification of many needs for which audience approach the media (Raacke \& Bonds-Raacke, 2008). Online media including social media play prominent role in satisfying audience needs and as a result, various empirical findings (Chung \& Yoo, 2008; Kim, 2006; Messing \& Westwood, 2014; Raacke \& Bonds-Raacke, 2008; Ruggiero, 2000; Urista et al., 2009) use the need gratifications as the basis to explain the shift in the audience preferences and usage of the media.

The audience could only measure media efficiency based on their needs that are gratified by the media. The expectation that the online versions of the mainstream news media meet some needs as a mark of differentiation from the offline media market would make the audience outside the reaches of the media consume the online versions. The uses and gratifications derived from the online versions of the mainstream news media are hinged on how accessible the audience find the media in a time of needs; how credible they consider the contents of the media they consume to meet their needs; and how interactive the media to ensure an active audience. This study, like many previous others on similar focus, approached need gratifications from audience-media preference and usage frequency emanating from the information needs of the audience and the level of satisfaction derived from the media (Kim, 2006; Ruggiero, 2000). It is safe of the criticism, "audience needs are neglected", since the need to be satisfied drives media preference.

\section{METHOD}

A survey was conducted regarding the audience perception of the efficiency of the online media. An online questionnaire was administered to elicit responses from the audience of Nigerian media in diaspora regarding the efficacy of the online version of the Nigerian mainstream media. Using available sampling technique, 52 Nigerians in Malaysia, UK, South Africa, and the US responded to the survey. Questionnaire items were structured to measure accessibility, credibility and interactivity of the online version of the three major mainstream media (newspaper, radio and television). After the expiration of three weeks (May 2nd to May 23rd, 2017) schedule for the completion of the online questionnaire with a time-to-time e-mail message to remind the respondents of the deadline, only 52 completed questionnaires were generated.

Due to the small size of the sample and non-parametric nature of the data generated for the analysis in this study, Smart Partial Least Squares (SmartPLS) Path Model approach to Structure Equation Modelling (SEM) was employed. The model was considered suitable owing to its graphical representation of complex relationships among variables as well as constructs, which could be presented in a simple, convenient, and explanatory way to even those who are always scared of numbers while reading research reports (Monecke \& Leisch, 
2012). SmartPLS also does not require distribution of assumption by specifying specific sample size or multivariate normality of the data making it suitable and appropriate for the analysis of various ranges of data (Hair, Sarstedt, Ringle, \& Mena, 2012; Henseler, Ringle, \& Sinkovics, 2009). The programme does not only accommodate small sample size but also ensure precision regardless of sample size, plausible for the small size of the sampled respondents in this study. It as well does not assume normality of data; it accommodates and processes data that are not normally distributed such as the type generated for this study.

Based on the data generated for the study, the following hypotheses were put to test to explain the significant factors of the online media efficiency and their variance contributions:

\section{HYPOTHESES}

H1a: Access to the online newspaper is not a significant factor in the online media efficiency.

$\mathrm{H1b}$ : Credibility of the online newspaper is not a significant factor in the online media efficiency.

H1c: Interactivity of online newspaper is not a significant factor in the online media efficiency.

H2a: Access to online TV is not a significant factor in the online media efficiency.

$\mathrm{H} 2 \mathrm{~b}$ : Credibility of online TV is not a significant factor in the online media efficiency.

$\mathrm{H} 2 \mathrm{c}$ : Interactivity of online TV is not a significant factor in the online media efficiency.

H3a: Access to online radio is not a significant factor in the online media efficiency.

$\mathrm{H} 3 \mathrm{~b}$ : Credibility of online radio is not a significant factor in the online media efficiency.

$\mathrm{H} 3 \mathrm{c}$ : Interactivity of online radio is not a significant factor in the online media efficiency.

\section{FINDINGS}

Preliminary analyses were carried out to establish the validity and reliability of the data and the constructs. Items with outer loading less than 0.5 (minimum requirement), which is the standard for a reflective model, were deleted. Convergent validities for the latent variables are achieved as Average Variance Extracted is above the minimum assumption (AVE >0.5) in each (Monecke \& Leisch, 2012). Internal Consistency Reliabilities for the latent variables are also achieved as Composite Reliability for each is above the minimum requirement (Composite $\geq 0.7$ ) as shown in table 1 .

Table 1: Algorithm Analyses for Validity \& Reliability

\begin{tabular}{lrrrrr}
\hline & AVE & $\begin{array}{c}\text { Composite } \\
\text { Reliability }\end{array}$ & $\begin{array}{c}\text { R } \\
\text { Square }\end{array}$ & Communality & Redundancy \\
\hline Efficiency & 1 & 1 & 0.2152 & 1 & -0.0133 \\
Newspaper-Accessibility & 0.5995 & 0.8535 & 0 & 0.5995 & 0 \\
Radio-Accessibility & 0.5818 & 0.7352 & 0 & 0.5818 & 0 \\
TV-Credibility & 0.6193 & 0.7549 & 0 & 0.6193 & 0 \\
\hline
\end{tabular}


The discriminant validity assumption requires that the correlations among the latent variables must be less or equal to \pm 0.9 in order to ensure that the variables have a significant level of freedoms from one another with each having the strongest relationship with its own indicator (items) than any other (Henseler et al., 2009). None of the correlation relationships among the variable violates the assumption as shown in table 2 (Correlations among the latent variables $\leq \pm 0.9$ ).

Table 2: Latent Variables Correlation

\begin{tabular}{lrrrr}
\hline & Efficiency & $\begin{array}{c}\text { Newspaper } \\
\text { Accessibility }\end{array}$ & $\begin{array}{c}\text { Radio } \\
\text { Accessibility }\end{array}$ & $\begin{array}{c}\text { TV } \\
\text { Credibility }\end{array}$ \\
\hline Efficiency & 1 & & & \\
Newspaper-Accessibility & 0.1923 & 1 & & \\
Radio-Accessibility & -0.2020 & 0.5500 & 1 & \\
TV-Credibility & 0.2242 & 0.0856 & 0.0415 & 1 \\
\hline
\end{tabular}

Accessibility of the Nigerian online newspapers is more pronounced by the respondents than other variables used to measure online media efficiency as all the items that measure the variable are statistically significant as shown in Table 3. It could be deduced that it is not only easy to access Nigerian online newspapers but also simple to navigate the sites during advanced information search. All items measuring the credibility of Nigerian online newspapers are also statistically significant. It denotes that information in the online versions of Nigerian newspapers are more objective, balanced, factual, and detail than those in the offline versions.

None of the other variables has all its measurement items significant. None of the items measuring newspaper interactivity, radio interactivity as well as television accessibility is statistically significant while two items each measuring radio accessibility and television credibility are significant.

Table 3: Bootstrapping Analysis for Items and Constructs Significant Test

\begin{tabular}{|c|c|c|}
\hline Items & & $\begin{array}{c}\text { T Statistics } \\
(\mid \mathrm{O} / \\
\text { STERR } \mid)\end{array}$ \\
\hline NPa1 <- NP-ACC & It is very easy to access Nigerian online newspapers & $3.7844^{*}$ \\
\hline $\mathrm{NPa} 2<-\mathrm{NP}-\mathrm{ACC}$ & Nigerian online newspapers sites are always available & $4.1225^{*}$ \\
\hline $\mathrm{NPa} 3<-\mathrm{NP}-\mathrm{ACC}$ & $\begin{array}{l}\text { It is very simple to navigate Nigerian online newspapers } \\
\text { sites for advance information search. }\end{array}$ & 3.2484 * \\
\hline $\mathrm{NPa} 4<-\mathrm{NP}-\mathrm{ACC}$ & The media site could be accessed with low internet network & $2.9338 *$ \\
\hline $\mathrm{NPb} 1<-\mathrm{NP}-\mathrm{CR}$ & $\begin{array}{l}\text { Messages in the Nigeria online newspapers are more } \\
\text { balance compare to offline }\end{array}$ & $2.7989 *$ \\
\hline $\mathrm{NPb} 2<-\mathrm{NP}-\mathrm{CR}$ & $\begin{array}{l}\text { Messages in the Nigeria online newspapers are more } \\
\text { objective compared to offline }\end{array}$ & $2.5243 *$ \\
\hline
\end{tabular}




\begin{tabular}{|c|c|c|}
\hline $\mathrm{NPb3}<-\mathrm{NP}-\mathrm{CR}$ & $\begin{array}{l}\text { Messages in the Nigeria online newspapers are more factual } \\
\text { compared to offline }\end{array}$ & 2.6135 * \\
\hline $\mathrm{NPb} 4<-\mathrm{NP}-\mathrm{CR}$ & $\begin{array}{l}\text { Messages in the Nigeria online newspapers are more } \\
\text { detailed compared to offline }\end{array}$ & $2.8961 *$ \\
\hline NPc1 <- NP-INTER & $\begin{array}{l}\text { There is more room for feedback advantage in the online } \\
\text { newspaper than offline }\end{array}$ & 0.9705 \\
\hline NPc4 <- NP-INTER & Online newspapers enhance active audience & 1.3171 \\
\hline Radioa1 <- RAD-ACC & It is very easy to access Nigerian online radio networks & $2.4776^{*}$ \\
\hline Radioa3 <- RAD-ACC & $\begin{array}{l}\text { It is very simple to navigate Nigerian online radio sites for } \\
\text { advance information search. }\end{array}$ & $2.164^{*}$ \\
\hline Radiob1 <- RAD-CR & $\begin{array}{l}\text { Messages in the Nigeria online radio are more balance } \\
\text { compare to offline }\end{array}$ & $4.1563^{*}$ \\
\hline Radiob2 <- RAD-CR & $\begin{array}{l}\text { e Nigeria online radio are more objective } \\
\text { fline }\end{array}$ & $3.9801 *$ \\
\hline Radiob4 $<-$ RAD-CR & $\begin{array}{l}\text { Messages in the Nigeria online radio are more detailed } \\
\text { compared to offline }\end{array}$ & $2.4202 *$ \\
\hline $\begin{array}{l}\text { Radioc1 <- RAD- } \\
\text { INTER }\end{array}$ & $\begin{array}{l}\text { There is more room for feedback advantage in online radio } \\
\text { than offline }\end{array}$ & 1.8203 \\
\hline $\begin{array}{l}\text { Radioc2 <- RAD- } \\
\text { INTER }\end{array}$ & $\begin{array}{l}\text { Nigerian Online radio create room for discussion forum } \\
\text { between the media and the audience and among the } \\
\text { audience }\end{array}$ & 1.7025 \\
\hline TVa1 <- TV-ACC & It is very to access Nigerian online television networks & 1.3974 \\
\hline TVa2 <- TV-ACC & Nigerian online television sites are always available & 0.8629 \\
\hline TVb3 $<-$ TV-CR & $\begin{array}{l}\text { eria online television sites are more } \\
\text { ine }\end{array}$ & 2.1589 * \\
\hline TVb4<- TV-CR & $\begin{array}{l}\text { Information on the Nigeria online television sites are more } \\
\text { detailed compared to offline }\end{array}$ & $4.4316^{*}$ \\
\hline TVc2 $<-$ TV-INTER & $\begin{array}{l}\text { Nigerian Online television sites create room for discussion } \\
\text { forum between the media and the audience and among the } \\
\text { audience }\end{array}$ & 3.4718 * \\
\hline
\end{tabular}

** Items with less than 0.5 outer-loadings were already suppressed.

* Items and construct below \pm 1.96 are not significant and therefore would be deleted in the final structural model (Hair et al., 2012).

Only three constructs; newspaper accessibility (H1a), television credibility (H2b) and radio accessibility $(\mathrm{H} 3 \mathrm{a})$ are statistically significant from the nine constructs in the bootstrapping analysis (Fig. 1). The significance of the three constructs indicates that the null hypothesis representing each would be rejected. The three constructs are therefore significant factors of the efficiency of online versions of the mainstream media. In contrary, the null hypotheses for statistical non-significant constructs are accepted as not being factors of efficiency of online versions of the mainstream media. 
Table 4: Hypotheses Testing

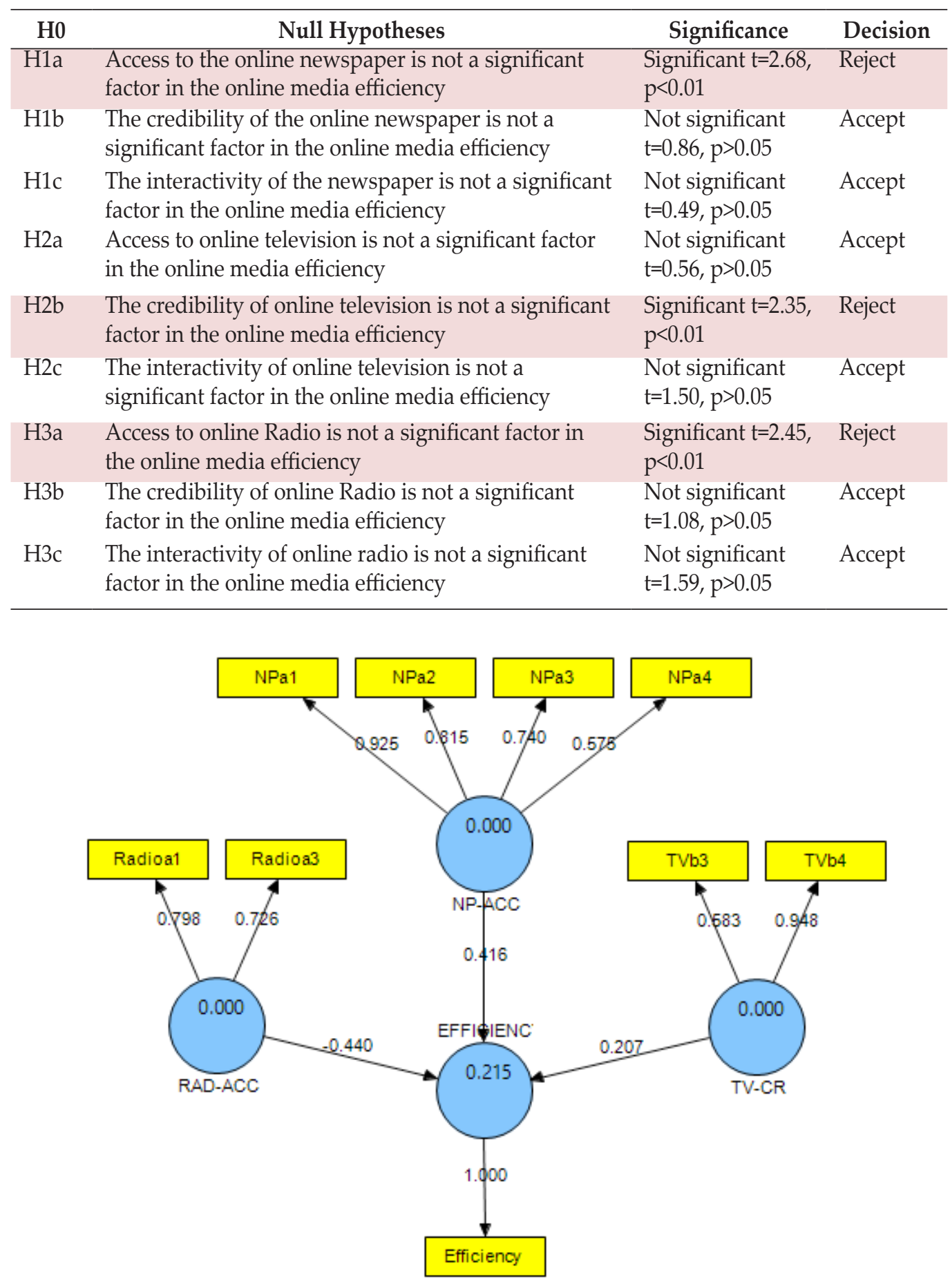

\section{Figure 2: Structural Model Showing Effect Size}

Findings from the structural model show that perceived access to the online newspaper is a significant predictor of the perceived online media efficiency $(t> \pm 1.96)$ with large positive 
effect $(\beta=0.42)$. It is a plausible effect to the rating of the media efficiency. Also, perceived credibility of online television is another significant predictor of the perceived online media efficiency $(t> \pm 1.96)$ with medium positive effect $(\beta=0.21)$. Perceived access to online radio is another significant predictor of the perceived online media efficiency $(t> \pm 1.96)$ but with large negative effect $(\beta=-0.44)$. This indicates that access to online radio was considered having detrimental effect on the efficiency of online version of Nigerian mainstream media. The three statically significant variables explain only $22 \%$ of the factors of online media efficiency $\left(\mathrm{R}^{2}\right.$ $=0.215$ ). Despite that none of the online mainstream media contributes significantly to the online media efficiency in term of level of interactivity; the online newspaper was perceived more interactive than radio and television counterparts.

\section{DISCUSSION}

Nigerians in diaspora consider the online versions of the Nigerian mainstream media not only as direct sources of essential information and news alerts from the country but also avenues to participate and contribute to discusses on topical issues affecting the country. The online version of the media was appraised for giving the opportunity to access news and relevant information which distance had once robbed them of. The efficiency of online versions of the mainstream Nigerian media in term of accessibility by the audience outside the country, credibility in term of content details and quality and interactivity that depict the level of audience involvement could refurbish the lost glory of the media. It portrays the means for the media not only to attract a prospective audience but also to win back and retain some of the audience segment lost to social media. The information need of the audience outside the border concerning the local contents of the mainstream media can only be met through the online platforms of the media. As a result, the satisfaction that the audience derives from the online media will go a long way in joining and retaining their interests.

Three variables were used to test for the efficiency of the online version of three mainstream media. The three hypotheses formulated are also in connection with the variables and were tested on each of the mainstream media. The respondents' consideration of the three categories of the mainstream media under each of the variables varies. Using similar constructs to elicit audience acceptability or rating of each of the mainstream media also produced different results.

Assessment of the accessibility to online newspapers shows that an overwhelming number of the online audience find it easier to visit the online newspapers sites than broadcast media sites. The newspaper sites are also found user-friendly as navigating from one page to another, sourcing the archive, selecting an edition, and contributing to issues reported are more simplified than those of online broadcast media. Availability of most of the online newspaper sites at every point of need is the most contributing factor for the higher rating of the online newspaper ahead of online radio and television. It is also the most favourable variables to an online newspaper out of the three variables used to ascertain the media efficiency.

The credibility of the online newspapers is not as enunciated as its accessibility and in overall, it is not considered a substantive factor that determines the efficiency of an online newspaper. Information and news items on online newspapers are not considered better off in term of balance presentation than those in offline newspapers or those in broadcast media. Also, Nigerian online newspapers are not perceived doing better than the offline versions or 
the broadcast counterpart in term of content objectivity. The audio-visual advantage in the broadcast media, which enhances the credibility of its content is still one of the measures used by the respondents while comparing the media. The contents of the online newspapers are considered more detail than those in offline or broadcast media. Some newspapers publish online exactly what they have in their offline versions, but the opportunity given for audience contribution to the online contents makes the latter more voluminous. It is perceived as an opportunity of having more details of the contents published as the news recipients analyse, criticise, clarify, and annotate the contents as supported by Bachmann (2010).

Despite that the online audience laud the interactive nature of the online newspapers, which give the opportunity to the audience not only to purge their opinions on issues published but also to rewrite and set record straight where media foul plays are suspected, it does not constitute a significant factor of the online newspaper efficiency. Diaspora audience emphasises that online newspaper versions create room for feedback advantage than the offline version. This is perceived breeds active audience and enhances participatory journalism as buttressed in Ahlers (2006). The access to the online newspapers was more prioritised by the diaspora audience than its interactive advantage.

Access to online radio is perceived partially influenced by how strong the internet facilities are. Connecting to radio spectrum online is consider heavy and consume more internet data perhaps because of the audio weight. Most of the diaspora audience considered that it is easier to access online newspaper than online radio. Navigating through online radio sites is as easy as navigating through newspaper pages online according to the audience. Despite that the access to online radio is influenced by the status of the internet facilities, it is found to be one of the significant factors that determine the efficiency of the online versions of the mainstream media in Nigeria as perceived by the audience (Ohaja).

The contents of online radios are applauded with a high rate of balanced reporting. Diaspora audience also perceived content as relatively objective with more focus on detail analyses of the local contents. However, the much praise of balanced and objective contents does not make the online radio credible enough to be one of the significant factors of the efficiency of the online version of the mainstream media in Nigeria as reflected in the results of the hypothesis. Similarly, the interactivity of online radio was not considered one of the significant factors that determine the perceived efficiency of the online version of the mainstream media in Nigeria. Although there is more room for feedback advantage in online radio than the offline version, which enhances the opportunity for discussion forum between the media and the diaspora audience and among the audiences from a different location, it is not as interactive as that of online newspapers (Ahlers, 2006; Moores, 1993).

Only the credibility of the online television was considered a significant variable of the efficiency of online versions of Nigerian mainstream media. Accessibility of the online television was perceived not satisfactory as the diaspora audience find an alternative in a subscription to television decoders to access local channels. Subscription to channel on Television decoders is not considered a substitute for online television as the former does not provide for the interactive forum, where the audience can contribute to the contents they consume. 


\section{CONCLUSION}

Having established that the audience rating of the efficiency of online versions of the mainstream media in Nigeria in respect to accessibility, credibility, and interactivity is not encouraging, it is unlikely that the audience resists the alternative media to satisfy their needs. Audience build trust around the media that meet their needs and consequently prioritise and use such media for information and communication needs. The urge by the mainstream media to revert their seemed lost audience rather than expanding market by establishing online versions is suffering from innovations that attract and sustain audience attention (Nguyen, 2008; Thurman, 2008). Audience participation in information generation and distribution through online newspapers is an indication that the traditional media are still essential information outlets that the diaspora audience cherishes once they are accessible online and they meet the audience information and communication needs. It is an avenue to boost development in communication and information sharing across borders.

\section{REFERENCES}

Adelakun, L. A. (2018). Trends in using social media as substitute for class interaction in open distance learning (ODL) education in Nigeria. International Journal of Pedagogy, Policy and ICT in Education, 6(1), 33-42.

Ahlers, D. (2006). News consumption and the new electronic media. Harvard International Journal of Press/Politics, 11(1), 29-52.

Bachmann, I., Kaufhold, K., Lewis, S., \&amp; Gil de Zúñiga, H. (2010). News platform preference: Advancing the effects of age and media consumption on political participation. International Journal of Internet Science, 5(1), 34-47.

Benson, R., Blach-Orsten, M., Powers, M., Willig, I., \& Zambrano, S. V. (2012). Media systems online and off: comparing the form of news in the United States, Denmark, and France. Journal of Communication, 62(1), 21-38.

Bucy, E. P. (2003). Media credibility reconsidered: Synergy effects between on-air and online news. Journalism \& Mass Communication Quarterly, 80(2), 247-264.

Chan, J. K. C., \& Leung, L. (2005). Lifestyles, reliance on traditional news media and online news adoption. New Media \& Society, 7(3), 357-382.

Chung, D. S., \& Yoo, C. Y. (2008). Audience motivations for using interactive features: Distinguishing use of different types of interactivity on an online newspaper. Mass Communication and Society, 11(4), 375-397.

Graham, G., \& Greenhill, A. (2013). Exploring interaction: print and online news media synergies. Internet Research, 23(1), 89-108.

Hair, J. F., Sarstedt, M., Ringle, C. M., \& Mena, J. A. (2012). An assessment of the use of partial least squares structural equation modelling in marketing research. Journal of the Academy of Marketing Science, 40(3), 414-433.

Henseler, J., Ringle, C. M., \& Sinkovics, R. R. (2009). The use of partial least squares path modelling in international marketing. Advances in International Marketing, 20(1), 277-319.

Kim, D. (2006). Abandoning traditional news? Examining factors influencing the displacement effects of online news on traditional news media: Southern Illinois: University at Carbondale.

Leung, L., \& Wei, R. (2000). More than just talk on the move: Uses and gratifications of the cellular phone. Journalism \& Mass Communication Quarterly, 77(2), 308-320. 
Messing, S. \& Westwood, S. J. (2014). Selective exposure in the age of social media: endorsements Trump partisan source affiliation when selecting news online. Communication Research, 41(8), 1042-1063.

Mitchelstein, E., \& Boczkowski, P. J. (2009). Between tradition and change A review of recent research on online news production. Journalism, 10(5), 562-586.

Monecke, A. \& Leisch, F. (2012). semPLS: Structural equation modeling using partial least squares. Journal of Statistical Software, 48(3), 1-32.

Moores, S. (1993). Interpreting audiences: The ethnography of media consumption (Vol. 8). London: Sage.

Nguyen, A. (2008). Facing “The Fabulous Monster" The traditional media's fear-driven innovation culture in the development of online news. Journalism Studies, 9(1), 91-104.

Nguyen, A. \&Western, M. (2006). The complementary relationship between the internet and traditional mass media: the case of online news and information. Information Research: An International Electronic Journal, 11(3), 17-38.

Ohaja, E. U. (2015). Buttressing the need for ethical guidance for online reporting in Nigeria. New Media and Mass Communication, 38, 13-23.

Raacke, J., \& Bonds-Raacke, J. (2008). MySpace and Facebook: Applying the uses and gratifications theory to exploring friend-networking sites. Cyberpsychology $\mathcal{E}$ Behavior, 11(2), 169-174.

Ruggiero, T. E. (2000). Uses and gratifications theory in the 21st century. Mass Communication ESociety, 3(1), 3-37.

Thurman, N. (2008). Forums for citizen journalists? Adoption of user generated content initiatives by online news media. New Media \& Society, 10(1), 139-157.

Tsfati, Y. (2010). Online news exposure and trust in the mainstream media: exploring possible associations. American Behavioral Scientist, 54(1), 22-42.

Urista, M. A., Dong, Q., \& Day, K. D. (2009). Explaining why young adults use MySpace and Facebook through uses and gratifications theory. Human Communication, 12(2), 215-229.

Wojcieszak, M. (2009). “Carrying online participation offline"-mobilization by radical online groups and politically dissimilar offline ties. Journal of Communication, 59(3), 564-586. 